InVisible Culture • Issue 33: After Douglas Crimp

\title{
After Douglas Crimp \\ Questionnaire Response: \\ Shota T. Ogawa
}

\section{Shota T. Ogawa}

Published on: Jan 05, 2022

DOI: 10.47761/494a02f6.0e17eab6

License: Creative Commons Attribution 4.0 International License (CC-BY 4.0). 


\section{Share an anecdote or memory you have of Douglas. Or, if you had the opportunity to share anything with Douglas now, what would it be?}

As an outsider to contemporary art, I can only write about Douglas in Rochester: not the New York City art critic, but a teacher and mentor who was unbelievably available and generous even for a student who he did not advise. I cannot forget driving through snowy downtown Rochester in his old Nissan Sentra (later, a black VW Beetle), listening to his Met Opera cassette tapes, when he would kindly lend me his car during the months and weekends that he would spend back in New York City. I know I was one of the many (usually overseas) students that got to use his cars and accompany him as his designated driver to and from the airport for his weekends back in New York City.

\section{In Before Pictures, Douglas describes navigating between academia, life outside, and how each informs the other. Discuss leisure, and how academic work reflects personal life, or vice versa.}

On rare weekends that he stayed in Rochester without flying back to New York City, I got to occasionally accompany him to the weekly public demonstration of the Italian Baroque organ at the Memorial Art Gallery (to be sure, I believe it was important that Eastman Rochester Organ Initiative is a rigorous research and education program with a global prestige) or find him at Dryden Theater at George Eastman Museum. These were occasions where I would see Douglas invariably finding the performer or the projectionist afterward to pose technical questions which appeared to come from a nebulous territory in between simple curiosity and critical close reading. I can see how his conversations about the materiality of film with Dryden Theater's head projectionist informed Our Kind of Movies: The Films of Andy Warhol. I never asked how or why he was interested in baroque organ music (he also attended the annual festival of organ music that gathered performers and musicologists from around the world), and I suspect he would have resisted a question that assumed one's interest was either entirely academic or for pleasure.

Shota T. Ogawa is a film researcher at Nagoya University and was a VCS student from 2007 to 2014.

Click here to return to the other questionnaire responses. 